\title{
Emerging Legal Strategies: Judicial Intervention
}

\author{
By Joseph L. Sax
}

Abstract: Citizen-initiated environmental litigation is a response to the inability of traditional administrative agencies to accommodate to newly recognized ecological perspectives in the management of natural resources. Old-line agencies, freighted by single-mindedness, a particular sense of mission and alignment with limited constituencies, are often unequal to the broadened perspectives which modern legislation and new public attitudes demand of them. Highway departments, for example, are charged with continuing to attend to the building of the "shortest, cheapest and straightest" roads, minimizing or ignoring new mandates to concern themselves with the environmental effects of their work. In consequence, important policy decisions are undermined or distorted. Judicial assistance is sought to return important policy decisions to a forum in which democratic processes work more effectively. One such incipient technique is the judicial "remand" of administrative action to the legislatures.

Joseph L. Sax, J.D., Ann Arbor, Michigan, is Professor of Law at the University of Michigan. He teaches natural-resources law, and is on leave this year completing a book on legal strategies for dealing with problems of environmental-quality management. 
T NVIRONMENTAL problems are C not a novelty in American courtrooms. Courts have traditionally abated pollution as a nuisance, and it is quite common for public agencies to obtain judicial enforcement of their orders regulating the use of land, water, and air. In the last few years, however, a new kind of litigation has developed which portends a dramatically different role for the judiciary: The plaintiffs are usually private citizens rather than government agencies; and they sue to enforce rights which they assert as members of the general public, not as property-owners seeking to protect conventional economic interests. Moreover, the governmental agencies which are supposed to be protecting the public interest are often themselves cited as defendants.

Such citizen-initiated litigation is typified by suits against highway departments challenging the necessity or location of a proposed road; ${ }^{1}$ actions by local citizens against the United States Forest Service challenging its management of public lands; ${ }^{2}$ and suits to enjoin offshore oil-drilling ${ }^{3}$ or a proposed airport extension which, it is alleged, will adversely affect scenic or wildlife resources.

In the past, such cases were routinely dismissed at the outset, both because the government was immune from suit and because it was said that private citizens had no "standing" to represent the public interest. ${ }^{5}$ The so-called sover-

1 Citizens' Committee for the Hudson Valley v. Volpe, 302 F. Supp. 1083 (S.D.N.Y. 1969); Road Review League v. Boyd, 270 F. Supp. 650 (S.D.N.Y. 1967).

2 Parker v. United States, Civil No. C-1368 (D. Colo., filed Jan. 7, 1969); Sierra Club v. Hickel et al., Civil No. 51,464 (N.D. Cal., filed June 5, 1969).

3 Weingand v. Hickel, No. 69-1317-EC (S.D. Cal., filed July 10, 1969).

4 Abbot v. Osborn, No. 1465 (Super. Ct., Dukes County, Mass., filed March, 1969).

5 National Parks Ass'n. v. Udall, Civil No. 3904-62 (D.D.C. 1962). eign-immunity doctrine--based largely on the ancient notion that "the king can do no wrong"- - has long been discredited as a viable legal theory, and has gradually (though not yet fully) dissipated as an effective defense.

The "standing" doctrine has only recently come under full-scale attack, but it, too, is rapidly losing ground. Courts used to accept unquestioningly the assertion that if citizens were allowed to sue simply as members of the public, the way would be open to a plethora of crank suits. And such suits were thought unnecessary because public officials stood ready to vindicate the public interest. Judicial attitudes toward standing have changed markedly in the last few years. In a recent case, in which local citizens intervened to challenge a radio license renewal by the Federal Communications Commission, the court said: ${ }^{\circ}$

The theory that the Commission can always effectively represent the listener interests ... without the aid and participation of legitimate listener representatives fulfilling the role of private attorneys general is one of those assumptions we collectively try to work with so long as they are reasonably adequate. When it becomes clear ... that it is no longer a valid assumption which stands up under the realities of actual experience, neither we nor the Commission can continue to rely on it. ... We cannot fail to note that the long history of complaints ... had left the Commission virtually unmoved. ... $[\mathrm{T}]$ he renewal application might well have been routinely granted except for the determined and sustained efforts of [the complaining citizens] at no small expense to themselves.

The withdrawal of technical barriers to suit is an important step, but it only sets the stage for the inquiry which courts must undertake once the curtain

${ }^{6}$ Office of Communication, United Church of Christ v. Federal Communications Comm'n., 359 F.2d 994 (D.C. Cir. 1966). 
is drawn back from the process of administrative decision-making. For if it is true that private initiatives are needed to provoke, and at times to displace, administrative agencies charged with protecting the public interest, grave questions are raised about the whole structure of governmental regulation in which we have invested so much of our trust.

If courts were only being asked to correct legal missteps by the agencies in such cases, or to intervene in those rare cases where "arbitrary and capricious action" were said to be involved, the implications would not be so farreaching. But it is clear that this is not at all the import of most citizeninitiated litigation. Rather, judges are being asked to look behind the exercise of administrative discretion. The charge, bluntly put, is that agencies are not to be trusted to effectuate the public interest; and not simply that they may have misread their statutory mandate in a given case.

It is the agencies' perspective and point of view which is under attack. Judicial uneasiness about this question has become overt in recent decisions. In the radio-licensing case, for example, the court noted that the Commission evinced a "curious neutrality in favor of the licensee," an attitude which put their handling of the matter "beyond repair" by the usual judicial technique of a remand to the Commission for further proceedings according to proper legal standards. The court took the unusual step of revoking the license itself.

Similarly, in recent Massachusetts cases, ${ }^{7}$ in which citizens challenged the highway department's decision to take park land for its own use, the court noted a disturbing insensitivity on the

${ }^{7}$ Sacco v. Department of Public Works, 352 Mass. 670, 227 N.E. 2nd 478 (1967) ; Robbins v. Department of Public Works, 214 N.E. 2d 577 (1969). part of the highway agency to the state's concern for the maintenance of pubic parks. The defendant highway department claimed it had ample authority under a broad statute which authorized it to "improve" the lands of the commonwealth; thus, it said, it could take park land at will, and its decision to do so must be respected by the judiciary. This was too much for the Supreme Judicial Court of Massachusetts. Plainly annoyed by such arrogance, the court responded:

The improvement of public lands contemplated by this section does not include the widening of a State highway. It seems rather that the improvement of public lands which the legislature provided for ... is to preserve such lands so that they may be enjoyed by the people for recreational purposes.

The court held that before the highway department could take park land, it had to go to the legislature and obtain specific authorization.

Judicial disenchantment with the administrative process is by no means new; but contemporary concerns about the environment have cast the problem in a new light; for they have brought home to courts the insufficiency of traditional institutions for dealing with the multiperspective, or ecological, approach which intelligent environmental management implies. Although it was never true that construction of a highway involved only problems of highway engineering, for a long time we seemed satisfied if highway-building agencies acted honestly and according to accepted engineering principles. We asked no more of them, and judicial review of their conduct could thus be limited to the question whether they were violating statutory standards, or acting arbitrarily.

Those narrow standards no longer suffice. We have come to recognize that a highway project goes beyond the 
problem of facilitating traffic, and may involve issues of housing, water-pollution, demographic patterns, and a host of other questions. Our perspective has broadened, and a number of statutes now require, for example, that projectbuilding agencies take account of local problems and of all reasonable alternatives to the disruption of parks, wildlife and waterfowl refuges, historic sites, and scenic attractions. Even such prosaic matters as dredge-and-fill permit applications filed with the Corps of Engineers must be referred to state and federal fish and wildlife agencies for consideration of their effects on such resources.

The new breadth of vision is commendable; but there is a wide gap between legislative statements of purpose and fulfillment on the part of deeply entrenched bureaucracies. A traditional single-purpose agency-long committed to getting roads built or rivers dredgeddoes not become an environmental ombudsman by legislative fiat. An agency staffed principally with highway engineers, long accustomed to dealing with certain limited groups in the community, and with a well-established sense of mission and priorities, is not easily transformed. Recent congressional hearings, ${ }^{8}$ for example, revealed that long after the enactment of the Fish and Wildlife Coordination Act, imposing upon the Corps of Engineers responsibility for the aquatic environment, even its formal public notices continued to say:

The decision of the Department of the Army must be based on the effect the proposed work would have upon navigation, and not on its effect on property values or other considerations having nothing to do with navigation.

\footnotetext{
8 Estuarine Areas, Hearings Before a Subcommittee on Fisheries and Wildlife Conservation, Committee on Merchant Marine and Fisheries, House of Representatives, 90th Cong., 1st Sess., Serial No. 90-3 (1967).
}

Congressional pressure brought about a formal restatement of function, but one need only visit a local Corps office for a brief chat to wonder how much-in outlook, in perspective, and in factthat agency has modified its traditional stance as a single-minded, navigationoriented enterprise.

It is this dilemma which has been brought so forcefully to the attention of the courts in the last few years. And judges, who used to say confidently that they ought not to substitute their judgment for the "expertise" of administrators, have begun to ponder whether and to what extent the expertise of the highway department is to be deferred to when the question is highways versus parks.

The problem is not merely that a traditional agency may lack the range of technical expertise needed to evaluate the diverse issues being presented, or that they may have a sense of mission about their function which tends to make them less than disinterested; or even that they have a history of close dealings with certain interests and industries which represent only one of the perspectives to which they are supposed to be attuned. The new ecological perspective to which they have been asked to respond implements a fundamental modification in the nature of the questions before them. To ask an agency to accommodate the demand for roads with the demand for parks and low-cost housing is to thrust upon them farreaching public policy choices.

To make such choices, traditional administrative agencies are peculiarly illsuited. Their perspective, their narrowness of outlook, their considerable insulation from substantial segments of the public-the very things which make them attractive as a source of technical, managerial decisions-become serious detriments in an agency charged with the resolution of large policy issues. It 
is this problem which judges in the cases cited above intuitively sensed as they rejected the agency's demands for conventional deferential treatment.

The citizen-initiated lawsuit is thus principally an effort to open the decisionmaking process to a wider constituency and to force decision-making into a more open and responsive forum. The aid of courts is not sought so that judges will substitute their judgment for that of administrators either on engineering questions or on broad policy issues. Rather, the courts are sought out as an instrumentality whereby complaining citizens can obtain access to a more appropriate form for decision-making.

This phenomenon is more easily described than explained. In the Massachusetts highway-park disputes, the goal was to deprive the highway agency of ultimate authority over the policy question involved and to force the legislature openly to consider and resolve the issue presented by the cases. Technically, the court ruled that the highway department lacked adequate authority to seize park land at will. Essentially, however, the goal of the lawsuit was to put the issue before the legislature, where it would have to be confronted and resolved in the full light of public attention. The court thus ruled in the Robbins case:

It is essential to the expression of plain and explicit authority to divert parklands ... to new and inconsistent uses that there appear in the legislation not only a statement of the new use but a statement or recital showing in some way legislative awareness of the existing public use. In short, the legislation should express not merely the public will for the new use but its willingness to surrender or forego the existing use.

It is with holdings such as this that courts respond to citizen pressures to democratize the decision-making process as it affects issues of environmental quality. The effect of such holdings is suggested by a letter which the plaintiffs' attorney wrote, describing the events which followed the court's decision:

The Legislature of Massachusetts had more discussion over the Fowl Meadow [the parkland involved in the case] than almost anything else ... in 1969. . . After a Herculean effort, the House of Representatives in Massachusetts voted 134-90 to authorize a feasibility study of a westerly route, such as we have been working for. However, our local [highway] Department brought out its troops in the form of at least six men who spent most of the week in the State House and, after reconsideration, obtained a bill for an opposite route by the narrow score of 109-105. The Senate concurred after removing some amendments and the Governor signed the bill. However, the whole subject of super highway consctruction ... has been put into the hands of a seven-man commission which is to report whether any new highways are needed. ... In the meantime, the Governor has stated in public and written us that he will not permit the transfer of the requisite parkland.

To be sure, such litigation does not assure that the advocates of any given position will triumph, or that the legislature will necessarily produce a wise resolution. It does, however, help to move questionable environmental decision-making into a forum where issues of policy must be made and articulated openly, and where legislators must assess the political consequences of taking one position or another. Measured against a system which has been characterized by its responsiveness to particular and limited interest groups, by its singlemindedness and limited perspective, and by its penchant for quiet resolution of potential conflict (often revealed in the attitude that the less the public knows, the less trouble there will be), judicial intervention of the type described above is a significant step forward. 
In an area such as environmental quality, where we struggle so much to determine what our goals should be, it is instructive to recall, from time to time, the enormous difficulties encountered in getting public agencies to respond to those situations in which there is a substantial consensus about goals; and in which narrow-interest groups have learned to manipulate the governmental process to their own advantage, to the dismay and detriment of the dominant community. All too often the public is simply presented with a fait accompli.

It has been traditional to tell complaining citizens to take their problems to the legislature, or to assume that, ultimately, resort to the ballot box will assure effectuation of the public will. The electoral process, as those who have suddenly awakened to see the bulldozers at work well know, is a very blunt instrument. In the swirling multitude of issues that intervene between periodic elections, it is not easy to cast a ballot which clearly says, "I disapprove your highway policy, approve your stance on foreign aid, and abhor your farm policy." Nor is it very realistic to tell a troubled community to go to Congress and get a law enacted to stop a project which is to go forward within a matter of days or weeks.

We have a great deal of rethinking to do about our laissez faire attitudes and assumptions about the process of government. Among the very significant matters being raised by environmental litigation is whether, and to what extent, institutions like the judiciary can, and should, intervene to help make that process work more effectively. The technique described above-essentially a judicial remand to the legislature-is one device that is now being tested. In essence, it says, "Yes, the citizens should go to the legis'ature, but a court order may be needed to assure that they can get there in time, and under circumstances which help to assure that their voices will be heard." It may seem ironic that courts are needed to help make the legislative process work effectively; that citizens must come to the least democratic of the branches of government to make democracy work. But that is one of the intriguing questions now being explored under the label of environmental litigation. 